\title{
GOOD GOVERNANCE IN MUNICIPAL AND RURAL MUNICIPAL OFFICES OF LOCAL ADMINISTRATION IN POLAND
}

\author{
Witold Szumowski \\ PhD, Wroclaw University of Economics, ul. Komandorska 118/120, 53-315 Wroctaw, \\ Phone +48606215836, E-mail witold.szumowski@ue.wroc.pl
}

Received 0105 2019; Accepted 30062019

\begin{abstract}
Public governance constitutes an answer to the limitations regarding the possibilities of reforming public administration in the stream of new public management. One of the detailed concepts of public governance was originally formulated by the World Bank. Its use in practice is limited to operationalization through formulating a variety of indices which are usually dedicated to countries and regions. Scientific discourse lacks studies indicating the possibility of using good governance in public administration at the level of its smaller exponents such as the units of local self-government. Equally, there are no available results of research regarding the influence of the functioning of units of public administration according to the principles of good governance on their perception on the part of citizens. This study aims at operationalizing the concept of good governance through the formulation of a model of activity of local government administration according to the principles of good governance, as well as proposes a tool for evaluating the level of maturity of management solutions based on the concept of good governance. The research results regarding the level of compatibility of these offices with the rules of good governance are compared with the results of surveys examining opinions and levels of satisfaction among inhabitants of selected boroughs. The aim of this comparison was to find the answer to the question of dependence between the activities of local administration in accordance with good governance and satisfaction on the part of local inhabitants.

Keywords: good governance, local government, public governance.
\end{abstract}

JEL Codes: M10 D73.

\section{Introduction}

Effective functioning of the units of public administration is considered to be the condition in the development of regions, countries and societies. This well-known paradigm provided the basis for the formulation of principles of good governance proposed by the World Bank in the 1990s. This concept belonging in the stream of public governance (Jessop, 2007) was then further developed by other international banks (e.g. African Development Bank, Asian Development Bank) and organizations (e.g. United Nations, OECD, EU), governments and institutions of individual countries, as well scientists studying the issues of co-governance. An analysis of the proposals offered by the mentioned international institutions (World Bank, 1992; African Development Bank, 1999; Asian Development Bank, 1999; IFAD, 1999; Qudrat-I Elahi, 2009; OECD, 2010) regarding the proposed characteristics, in particular those of the

Copyright $\odot 2019$ The Authors. Published by Vytautas Magnus University, Lithuanian Institute of Agrarian Economics. This is an open-access article distributed under the terms of the Creative Commons Attribution-NonCommercial 4.0 (CC BY-NC 4.0) license, which permits unrestricted use, distribution, and reproduction in any medium, provided the original author and source are credited. The material cannot be used for commercial purposes. 
EU (Commission of the European Communities, 2001), as well as the analysis of literature on this subject (Piotrowski, Van Ryzin, 2007; Langton, 1978; Brodie E. et al, 2009; Drucker, 1963; Bovens 2010), allow to suggest the following principles of good governance:

- transparency - carrying out an active information policy in relation to the planned and undertaken actions and availing all the indispensable information resources to the potential stakeholders, including the implemented processes and procedures (excluding the information which should remain confidential for reasons of public interest).

- $\quad$ participation - carrying out actions based on transparency which enable the interested parties to participate in the processes of decision-making by the authorities. Participation requires both the existence of mechanisms facilitating cooperation and undertaking steps aimed at the involvement of interested stakeholders.

- $\quad$ efficiency and effectiveness - establishing and achieving, through the activities of the public administration, the goals serving to satisfy the needs of the citizens, and at the same time aiming at minimizing the costs associated with these activities and the best possible use of the available resources.

- $\quad$ accountability - informing stakeholders, and in particular explaining and justifying actions undertaken by the authorities and the results thereof, whilst the stakeholders are entitled to ask questions and offer their judgement, and the subject under scrutiny may be held to account.

- $\quad$ cohesion - the scope of mutual compatibility between the individual elements in an organization and adaptation of these elements to their environment (in particular strategies, which in the case of public institutions is linked to, among others, planning and coordination of implemented policies).

However, when looking at the literature on this subject it can be noted that the operationalization of good governance is limited only to the level of countries and regions, and is usually presented as sets of various types of indices (Knack, Kugler, 2002; Besançon, 2003), whilst academic discourse linked with the concept of good governance mostly concentrates on the issues of its definition. What is missing is the analyses indicating the possibility and practicality of implementing the principles of good governance in relation to the processes of managing offices of local administration and units of local government administration. The answer to the question of the practicality and effects of applying the concept of good governance in managing the units of local government administration requires the operationalization of the concept of good governance in relation to the level of governance of the local administration offices, measuring the level of maturity of the organization in implementing the principles of good governance, as well as defining the dependence between the application of this concept in management of a unit of local government administration, evaluation of its activity and the satisfaction of the local community.

The existing practice regarding the implementation of the concept of good governance in order to construct sets of indices related to countries or regions seems to indicate the greater purposefulness of using the concept of good governance in 
managing large units. The author of this article verifies such a hypothesis by determining, through the process of empirical research, the existence of a dependence between the application of the principles of good governance in the offices of local government administration and the satisfaction with the local government activities on the part of local inhabitants. The results of research are diversified according to the type of municipality (rural, urban-rural, urban).

\section{Methods}

Determining the dependence between the use of the concept of good governance and the satisfaction on the part of the residents requires first the operationalization of the concept of good governance. For this purpose the author proposes a matrix of evaluations of the maturity levels of local administration offices, in which the areas of the evaluation were based on the most popular (Jones, Brazzel, 2006) models of organization in a systemic approach, such as the Weisbord model (Weisbord, 1976), the star model (Galbraith, 2006) as well as the 7S model (Waterman, Peters, Phillips, 1980). The three basic elements of public organization in which the application of the principles of good governance is most vital are: strategy, processes and people.

The dimensions of the proposed matrix ere defined using a dynamic approach based on the proposed process of forming individual areas of an organization according to the principles of good governance. From this perspective the starting point is to determine the stages in the process of design, realization and assessment of activities on the part of the offices of local government organization in all three areas. It has been assumed that this process, due to the need for implementing the principles of good governance, will follow a similar course. The basic scheme of forming the organization of an office of local government administration according to the principles of good governance is shown in Figure 1.

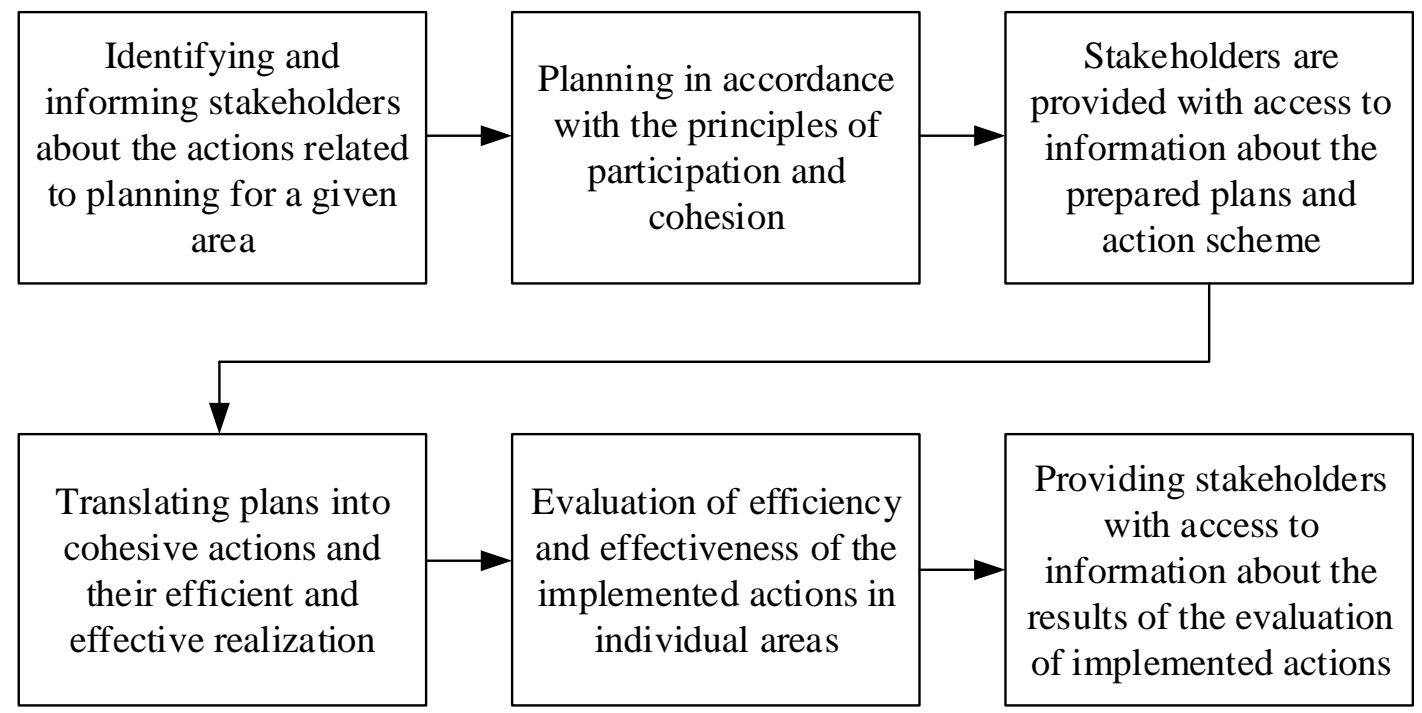

Fig. 1. Basic scheme of forming organization areas based on the principles of good governance 
The sequence of actions shown in Figure 1 can be translated into the following issues which are subject to evaluation regarding the area of adapting strategy to the principles of good governance:

1) transparency of design at the outset,

2) participation in the scope of planning which consists in:

- identification of stakeholders' needs,

- participation of stakeholders in planning solutions,

3) cohesion at the outset,

4) transparency of prepared plans,

5) cohesion at the outcome,

6) efficiency and effectiveness in the realization of plans,

7) accountability (public control mechanisms),

8) transparency of the achieved results.

A descriptive scale has been proposed for each of the listed stages which can be used to evaluate the degree of maturity of local government units in the scope of implementing the principles of good governance (see Table 1). In the majority of cases within the individual evaluated areas of organization (strategy, processes, people) there are unified proposed levels of maturity. Slightly different levels of maturity were suggested only for the area 'people' in relation to the principle of transparency. This is caused by the idiosyncrasy of this area in which principally the stakeholders are the employees of local administration offices. In the presented proposal, transparency at the lower levels means enabling access to information to the staff, whereas at the higher levels it means providing access to information for all the interested parties.

Table 1. Levels of maturity using the concept of good governance

\begin{tabular}{|c|c|c|}
\hline & & Processes \\
\hline \multirow{4}{*}{ 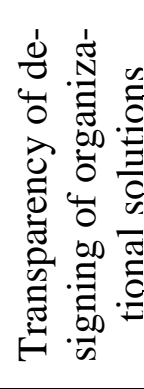 } & Level 3 & $\begin{array}{l}\text { The use of information channels is assessed, and the conclusions are used to im- } \\
\text { prove communication with stakeholders. }\end{array}$ \\
\hline & Level 2 & $\begin{array}{l}\text { The way of passing information and information channels are adapted to the spe- } \\
\text { cifics of the groups of stakeholders. }\end{array}$ \\
\hline & Level 1 & $\begin{array}{l}\text { Potential stakeholders are identified and then informed about the commencement } \\
\text { of the process of planning strategies / processes / solutions in HR. }\end{array}$ \\
\hline & Level 0 & $\begin{array}{l}\text { Stakeholders are not identified nor informed before the commencement of plan- } \\
\text { ning strategies /processes/solutions in HR. }\end{array}$ \\
\hline \multirow{4}{*}{ 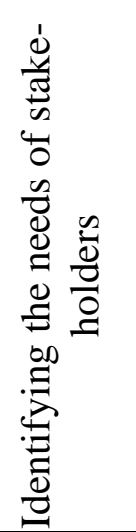 } & Level 3 & $\begin{array}{l}\text { Research on identifying the needs of local community is conducted regularly, } \\
\text { and the conclusions are included in the process of planning strategies /processes } \\
\text { /solutions in HR. }\end{array}$ \\
\hline & Level 2 & $\begin{array}{l}\text { Research on identifying the needs of the local community is conducted irregu- } \\
\text { larly while the conclusions are included in the process of planning strategies } \\
\text { /processes / solutions in HR. }\end{array}$ \\
\hline & Level 1 & $\begin{array}{l}\text { There are tools allowing for the assessment of stakeholders' needs in regard of } \\
\text { the desired strategies lways of implementing processes UHRM. Research is inci- } \\
\text { dental. }\end{array}$ \\
\hline & Level 0 & $\begin{array}{l}\text { Lack of tools allowing to identify the needs of stakeholders regarding desired } \\
\text { strategy, way of implementing processes, HRM. }\end{array}$ \\
\hline
\end{tabular}




\begin{tabular}{|c|c|c|}
\hline & & Processes \\
\hline \multirow{4}{*}{ 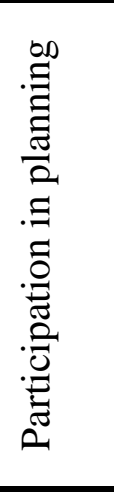 } & Level 3 & $\begin{array}{l}\text { Stakeholders participate in: planning strategy/ processes /solutions in HRM. De- } \\
\text { cisions are made in complete agreement with stakeholders' expectations. }\end{array}$ \\
\hline & Level 2 & $\begin{array}{l}\text { Stakeholders participate in: preparing strategy/ planning processes /working out } \\
\text { solutions in HR. Local authorities include in their decision-making these opinions } \\
\text { of the stakeholders which are deemed legitimate. }\end{array}$ \\
\hline & Level 1 & $\begin{array}{l}\text { Stakeholders are given an opportunity to participate in: preparing strategy/ plan- } \\
\text { ning processes / working out solutions in HR, e.g. through contributing comments } \\
\text { and suggestions for the planned solutions. }\end{array}$ \\
\hline & Level 0 & $\begin{array}{l}\text { Stakeholders are unable to participate in: preparing strategy/ planning processes / } \\
\text { working out solutions in HR. }\end{array}$ \\
\hline \multirow{4}{*}{ 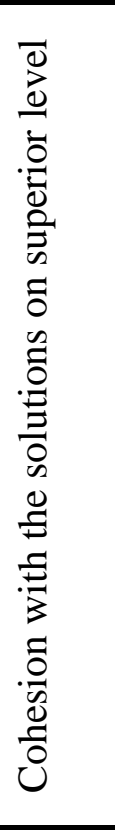 } & Level 3 & $\begin{array}{ll}\text { Designing strategy in- } & \text { A uniform system of HR solutions are linked to } \\
\text { cluded all the strategies } & \text { measures in the area of effi- personnel strategy. There } \\
\text { in the higher-level units } & \text { ciency and effectiveness in are mechanisms of measur- } \\
\text { and at national level. } & \text { realizing strategic goals and ing goals in HR, and goals } \\
\text { processes implemented in are monitored. } & \\
\text { the office was prepared. }\end{array}$ \\
\hline & Level 2 & $\begin{array}{l}\text { Designing strategy in- Key processes and HR solutions (e.g. system } \\
\text { cluded at least two measures of their efficiency of remuneration, bonus } \\
\text { higher-level strategies and effectiveness are de- } \\
\begin{array}{ll}\text { (county, regional, na- fined. } & \text { odical assessment) are tied } \\
\text { tional). } & \text { with personnel strategy. }\end{array}\end{array}$ \\
\hline & Level 1 & $\begin{array}{l}\text { Designing strategy in- } \\
\text { cluded designing processes / personnel strategy, its cohesion } \\
\text { higher-level strategies } \\
\text { (county, regional, na- } \\
\text { tional). }\end{array}$ \\
\hline & Level 0 & Lack of cohesion between the designed solutions and the higher-order solutions. \\
\hline \multirow{4}{*}{ 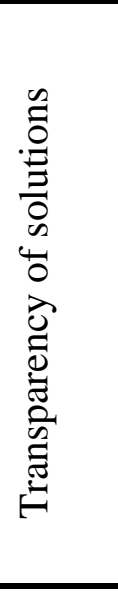 } & Level 3 & $\begin{array}{l}\text { Information about the borough's strat- Information about the solutions in HR is } \\
\text { egy/course of processes and regarding generally available for all the stakehold- } \\
\text { the adoption of stakeholders' postu- ers (including local residents). } \\
\text { lates, including notification about the } \\
\text { rejection of selected postulates and its } \\
\text { reasons is generally accessible }\end{array}$ \\
\hline & Level 2 & $\begin{array}{l}\text { Information about the borough's strategy / course of processes/ functioning solu- } \\
\text { tions in HR, is generally available to stakeholders. }\end{array}$ \\
\hline & Level 1 & $\begin{array}{l}\text { Information about: borough's strategy, course of processes, functioning solutions } \\
\text { in HR is available only when requested by stakeholders. }\end{array}$ \\
\hline & Level 0 & $\begin{array}{l}\text { Information about: the borough's strategy/ course of processes/ functioning solu- } \\
\text { tions in HR, is not made available. }\end{array}$ \\
\hline 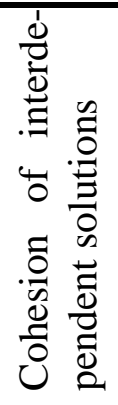 & Level 3 & $\begin{array}{l}\text { Realization of strate- All the connections be- The results of staff ap- } \\
\text { gies is subject to special tween the processes real- praisal are linked to deci- } \\
\text { supervision by the or- ized within the local office sions about: pay rises, job } \\
\text { gans of local admin- and processes realized by promotions, job training, } \\
\text { istration; there exist external unit have been in- downsizing, etc. } \\
\text { procedures in the scope cluded. The office super- } \\
\text { of MBO or BSC. } \\
\text { vises all the interconnected } \\
\text { processes. }\end{array}$ \\
\hline
\end{tabular}




\section{Witold Szumowski. Good governance in municipal and rural municipal offices of local}

administration in Poland

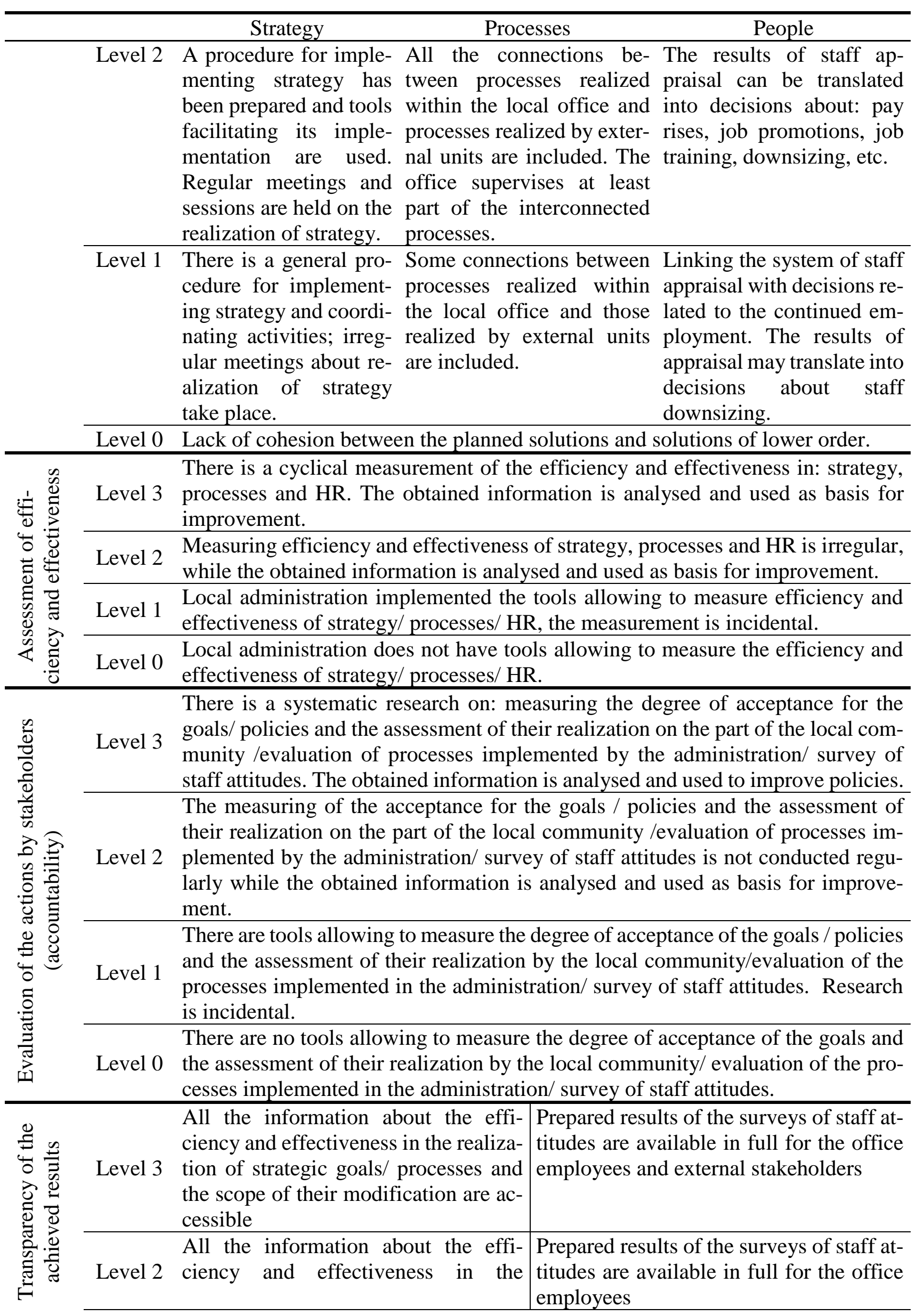




\begin{tabular}{|c|c|c|}
\hline & Strategy & \multirow[t]{2}{*}{ People } \\
\hline & $\begin{array}{l}\text { realization of strategic goals / pro- } \\
\text { cesses are generally accessible }\end{array}$ & \\
\hline Level 1 & $\begin{array}{l}\text { Information about the efficiency and } \\
\text { effectiveness in the realization of stra- } \\
\text { tegic goals /processes are made avail- } \\
\text { able following a demand made by } \\
\text { stakeholders }\end{array}$ & $\begin{array}{l}\text { Selected information about the outcome } \\
\text { of the survey of staff attitudes are com- } \\
\text { municated to the employees }\end{array}$ \\
\hline Level 0 & \multicolumn{2}{|c|}{$\begin{array}{l}\text { Information about the efficiency and effectiveness of realizing strategic goals / } \\
\text { efficiency and effectiveness of the implemented processes/ results of the con- } \\
\text { ducted research on staff attitudes are not passed on to the stakeholders. }\end{array}$} \\
\hline
\end{tabular}

The next step in the research procedure was to transform the proposed maturity model into a research tool in the form of a survey using a construction similar to that of the self-assessment survey CAF (Common Assessment Framework). In order to limit the margin of error arising from the declarative nature of the conducted research, in respect of each question examples of evidence were provided which confirmed the existing organizational state. Due to the limited possibility of presenting the tool, the author shows below an example of the question aimed at evaluating the maturity level in terms of informing stakeholders about the commencement of the formulation of strategic goals by a borough.

Table 2. Example of a research question

Please mark the answer describing the situation in your office

Answer

Are the potential stakeholders identified before the commencement of the process of preparing a strategy (or the preparation of plans, documents strategic for the borough)?

No $\quad$ Yes

Example of evidence for "YES": documenting the process of preparing a strategy

Are the previously identified stakeholders informed about the commencement of the process of preparing a strategy (or the preparation of plans, documents strategic for the borough)?

No $\quad$ Yes

Example of evidence for "YES": filed announcements, official correspondence

Are the ways of informing and the information channels adapted to the specific requirements of the groups of the informed stakeholders?

Example of evidence for "YES": filed announcements, official correspondence

No $\quad$ Yes

Are there conducted any actions aimed at the assessment of the efficiency of the applied information channels, and are the conclusions drawn from the assessment used in order to improve communication with stakeholders in the process of preparing a strategy (or the preparation of plans, documents strategic for the borough)?

No $\quad$ Yes

Example of evidence for "YES": reports from the conducted research, documents from the process of communication.

Other questions aimed at assessing individual areas have a similar structure. 
A computer-aided telephone interview (CATI) was selected as the method of data collecting, in which the respondents were Chief Executives of local administration offices, i.e. persons who are best informed in the matters of the functioning organizational solutions in a given administration. The survey was conducted in 2017 (pilot scheme) and 2018 (the research proper).

The subject of the conducted research concerned the offices of the local administration, of which 410 were questioned. In the sample of this size and for the assumed level of trust of 0.95 , the maximum statistical error amounted to $4 \%$. The choice of trial subjects was of the random-quota nature. Using the criterion of quota selection, due to the character of a borough represented by the office (rural, urban-rural, municipality, town with county rights), the obtained deviations of the trial structure in relation to the structure of local administration in Poland were at the level lower than 3 percentage points for each of the categories, and the value of the similarity index of structures ( $\omega \mathrm{p})$ reached 0.976 .

The applied research tool enabled to translate the obtained answers into numerical values in the interval $0-3$, where ' 0 ' means the absence of existing organizational solutions confirming the realization of a given principle of good governance in a particular aspect, and ' 3 ' marks the highest level of adaptation to the model proposed earlier.

The results of the research conducted in the local administration offices were analysed and are presented in further part of this article. To facilitate making the comparison and selecting offices of local government we have constructed a synthetic index which is an ordinary arithmetic mean for the values obtained in individual areas and dimensions.

Due to the aim of this article which is to define the dependence between the implementation of the principles of good governance in the local administration offices and the satisfaction of the local residents related to the local government activity, it was necessary to carry out the second stage of research aimed at establishing the level of satisfaction among the local community with the activity of units of local government.

The objects (boroughs) were selected based on the value results of the synthetic index of the adaptation of the management system to the concept of good governance. The method of equal intervals was accepted as a key premise in the choice of local administration offices representing different levels of adjustment to the concept of good governance. The number of classes (intervals) was determined using the formula:

$$
\mathrm{K}=1+3.322 \log \mathrm{n}
$$

For each class, three boroughs were selected at random, representing one of the three types (rural, urban-rural, urban and towns with the county status). An exception here proved to be the first interval consisting in the offices with the lowest level of the value of synthetic index of the implementation of the principles of good governance.

This class did not include municipal offices and because of that two rural boroughs were randomly selected. 


\section{Management Theory and Studies for Rural Business and Infrastructure Development eISSN 2345-0355. 2019. Vol. 41. No. 2: 135-152.}

In each of the 30 selected boroughs research was conducted in regard of the evaluation of the activity of local administration offices, based on a sample of 30 inhabitants. In this way the research involved 900 adults residing in Polish boroughs. As part of the survey the respondents were asked to evaluate the activities of the local government administration from the viewpoint of individual principles of good governance. To do this, the participants were asked to answer the questions related to their opinion on implementing individual principles of good governance by their local authorities and describing their satisfaction with these activities. The five-point Likert scale was used in this research. A maximum statistical error for the entire sample (in relation to the sampling frame of all adult inhabitants in Poland), assuming the level of trust 0.95, amounted to $3.3 \%$.

The research carried out in 2018 among inhabitants of the selected boroughs was divided into a pilot stage, which aimed at verifying the correctness of the research tool (in two boroughs on a sample of 60 residents), and the research proper.

\section{Results}

The results of the conducted research on the level of maturity of the offices of local government administration related to implementing the principles of good governance are presented in Table 3 and Figure 2.

The conducted analysis suggests that the highest degree of adjustment exists in the area of strategy. The high average value of this aspect results from its transparency interpreted as informing stakeholders about the undertaken actions related to preparing strategic documentation and the inclusion in the preparation of these documents of strategic plans made by the units from the higher level of local government (county and regional). Transparency is also understood here as access to strategic documents being prepared by the local government units.

The next area, from the viewpoint of adjustment to the proposed model, i.e. human resources management, the highest values of indices were achieved for efficiency and effectiveness - interpreted as the criterion of working efficiency used in periodic assessment of local government staff, transparency of planned solutions in the area of HRM, and consistency understood as the consistency of staff appraisal mechanisms with other actions and decisions made in relation to the management of human resources.

The lowest level of adjustment was observed in the area of process management which resulted from the frequent orientation on functions and not processes in the examined units. Most of them did not prepare paths of processes, which has a significant impact on the results obtained in this area.

Table 3. Mean values of indices of the maturity of the individual areas of management and dimensions of good governance $(n=410)$ 


\section{Witold Szumowski. Good governance in municipal and rural municipal offices of local}

administration in Poland

\begin{tabular}{|l|c|c|c|c|}
\hline Good governance dimension & Strategy & Processes & People & $\begin{array}{c}\text { Mean for } \\
\text { a dimen- } \\
\text { sion }\end{array}$ \\
\hline Transparency of designing on the outset & 1.97 & 0.72 & 1.73 & 1.47 \\
\hline Identification of stakeholders' needs & 1.08 & 0.43 & 0.42 & 0.64 \\
\hline Participation of stakeholders in planning solutions & 1.38 & 0.38 & 0.81 & 0.86 \\
\hline Cohesion at the outset & 2.27 & 0.58 & 0.32 & 1.06 \\
\hline Transparency of prepared plans & 2.21 & 0.55 & 1.02 & 1.26 \\
\hline Cohesion at the outcome & 0.26 & 0.36 & 1.52 & 0.71 \\
\hline Efficiency and effectiveness in realizing plans & 0.66 & 0.27 & 2.54 & 1.16 \\
\hline Accountability (public control mechanisms) & 0.36 & 0.40 & 0.51 & 0.42 \\
\hline Transparency of achieved results & 0.44 & 0.15 & 0.29 & 0.29 \\
\hline Mean for an area & 1.18 & 0.42 & 1.01 & 0.88 \\
\hline
\end{tabular}

The value of a synthetic index showing the general level of adjustment of the system of managing offices of local government administration to the concept of good governance was 0.88 for the whole sample. Value distribution for the synthetic index shows right-side asymmetry, and bias coefficient amounted to 1.12 , which means that in the examined sample, the offices representing a lower level of adjustment to the proposed model dominate. The bar chart below presents a division of the sample by the method of equal intervals, according to the value of synthetic index (Figure 2).

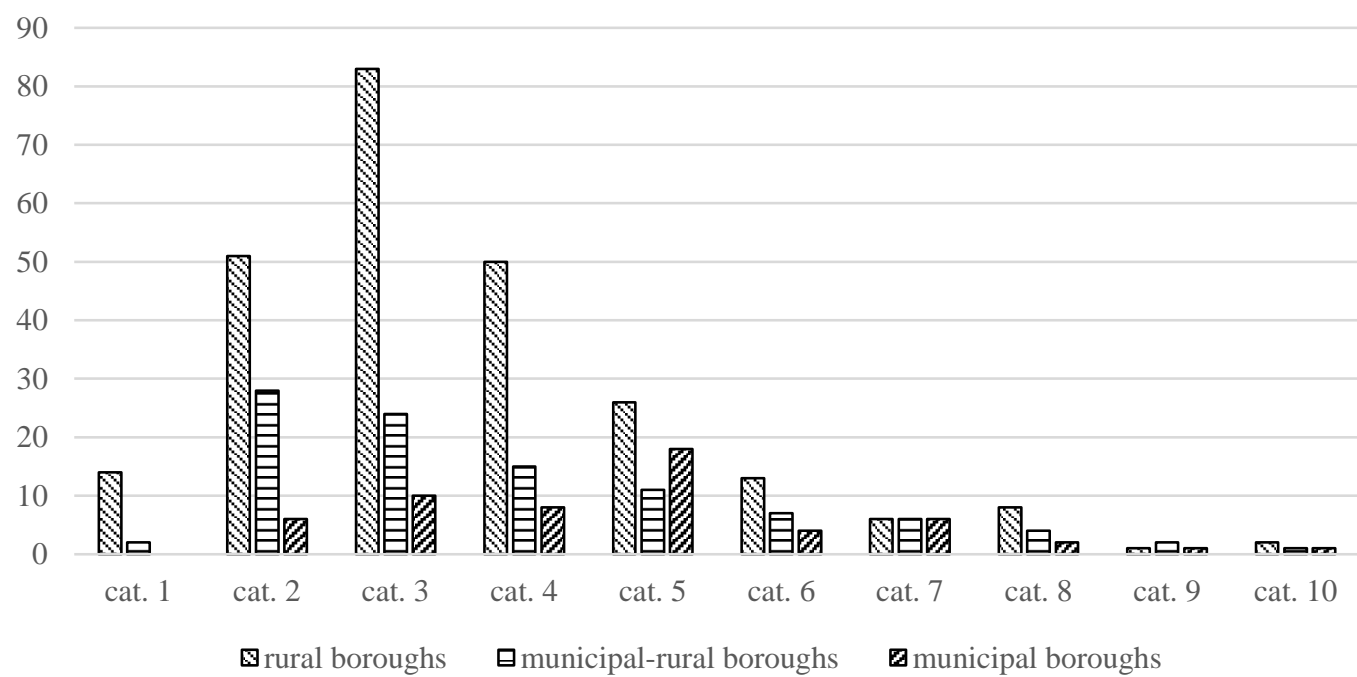

\begin{tabular}{|l|c|c|c|c|c|}
\hline Category & Cat. 1 & Cat. 2 & Cat. 3 & Cat. 4 & Cat. 5 \\
\hline Interval & $<0.11-0.34)$ & $<0.34-0.57)$ & $<0.57-0.8)$ & $<0.8-1.03)$ & $<1.03-1.26)$ \\
\hline Category & Cat. 6 & Cat. 7 & Cat. 8 & Cat. 9 & Cat. 10 \\
\hline Interval & $<1.26-1.49)$ & $<1.49-1.72)$ & $<1.72-1.95)$ & $<1.95-2.18)$ & $<2.18-2.41\rangle$ \\
\hline
\end{tabular}

Fig. 2. Intervals and their cardinality for a synthetic index of the maturity of a management system

It is worth noting that the scale of adjustment to the proposed model differs in individual types of boroughs. In municipal boroughs the mean value of the synthetic index was at 1.04 and distribution was almost symmetrical, while in rural boroughs the 
mean value was 0.82 . The indicated diversity is linked to the size of studied units. In the case of rural boroughs, small communities predominate in which the average number of inhabitants is 7046. In municipal boroughs the average number is 61,387 . The interdependence between the size of a borough expressed by the number of inhabitants and the value of the index representing the adjustment of the local administration to the proposed model of good governance equals 0.26 .

The linking of the scope of adjustment of the management system to the concept of good governance with the evaluation of the activities of local government units on the part of residents, as well as their satisfaction with such activities is a very significant issue. As was described in the methodology part, examining this relation necessitated research in selected boroughs in which offices of local administration represent varied level of adjustment to the proposed model of action according to the principles of good governance.

The results of the research conducted on evaluating the units of local government are shown in Figure 3.

Satisfaction

Accountability

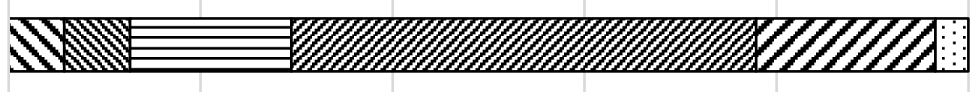

Cohesion

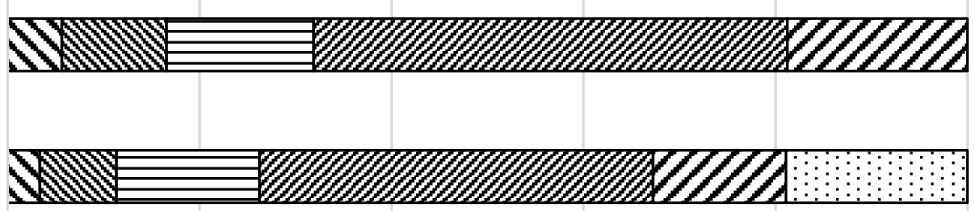

Efficiency and effectiveness

Participation
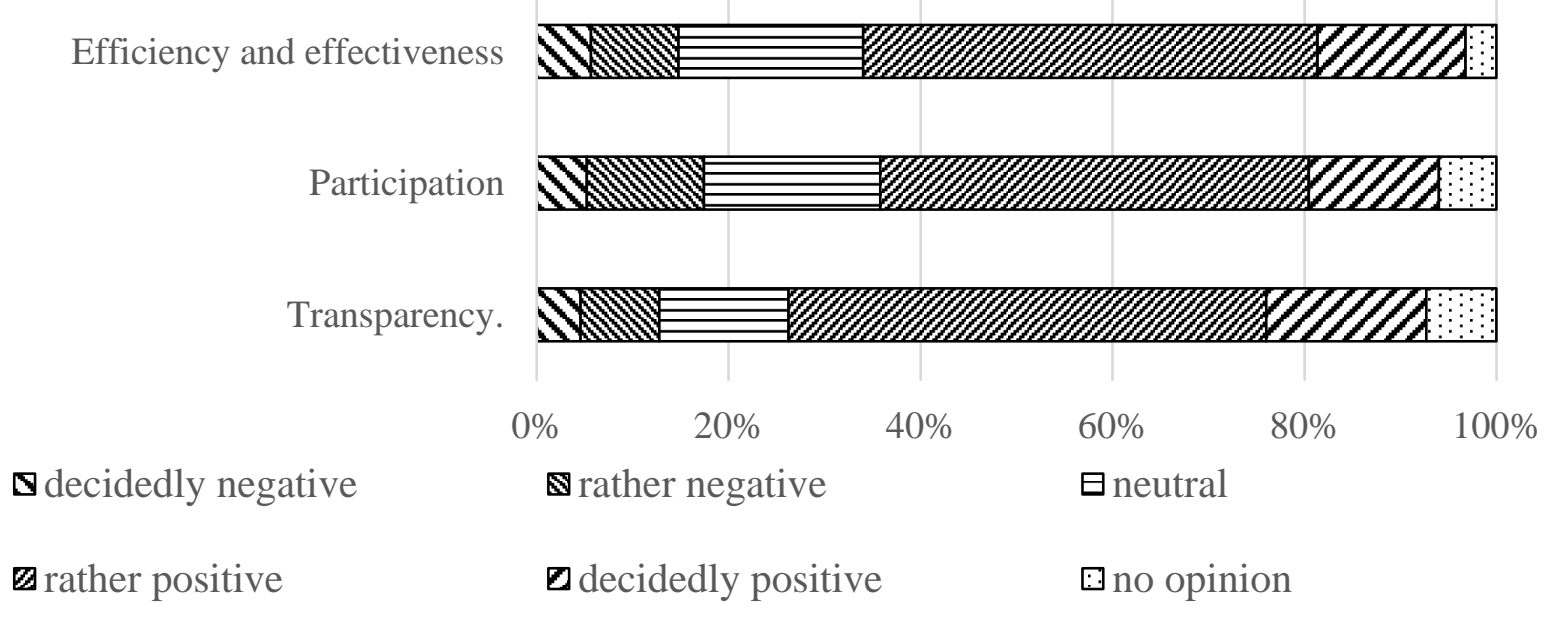

Fig. 3. Evaluation of activity by local administration from the viewpoint of implementing the principles of good governance

The conducted research suggests that in the majority of cases, local residents evaluate positively activities carried out by the units of local government in the context of adherence to principles of good governance. Their perception in this context is also 
linked to the satisfaction with the activities of local administration declared by the local community. The interdependence (correlation) between the average evaluation results regarding the adherence of local administration units to the principles of good governance and the declared satisfaction of the inhabitants amounts to 0.81 .

The analysis of the results also showed the existence of a negative correlation between the local population numbers and both the assessment of the implementation of the principles of good governance, and the satisfaction levels declared by the local residents.

This observation is relevant in the case of investigating a dependence between the implementation of the principles of good governance and the satisfaction of residents. This means that a variable which is the number of local inhabitants should be treated as a moderating variable. Therefore, a verification of a correlation between the use of principles of good governance by the local administration and its evaluation by local residents and their satisfaction, requires the application of path analysis, which is a technique based on multivariate analysis of regression. A starting point for this method is the proposed paths diagram (Figure 4).

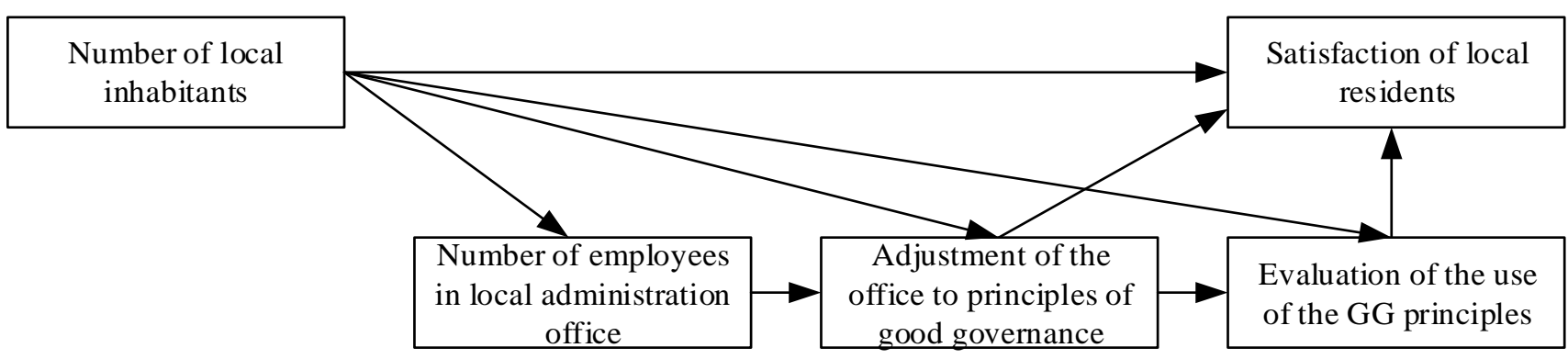

Fig. 4. Proposed outcome of a path diagram

The model presented above considers the existence of a relation between the degree of adjustment to the proposed model of functioning of local administration based on the principles of good governance and satisfaction declared by local residents. An additional assumption was the impact of perceived adherence to the use of principles of good governance on the satisfaction expressed by the inhabitants.

Moreover, the model included additional directional links taking into consideration the existence of intermediary variables. In the case of the impact of the use of principles of good governance by the local government offices on the local inhabitants' satisfaction this is a connection through an intermediary variable such as the evaluation by the local residents of the use of those GG principles.

When considering the influence of the number of residents on the level of maturity of the local administration office, the selected intermediary variable corresponded to the number of the office employees. Moreover, due to the existing statistically significant negative correlations between the number of inhabitants in a borough, the satisfaction of inhabitants and their evaluation of applying principles of good governance, we also had to consider the possibility of the existing influence of the size of a borough 
expressed by the number of inhabitants on the variables linked with a subjective evaluation made by the inhabitants.

For the purposes of the conducted analysis, we carried out a logarithmic conversion of two variables, the number of residents in a borough and the number of employees. In both cases this was necessary due to the extreme right-sided asymmetric distribution of variables and the existence of singular extreme-lag observations. In order to obtain a more symmetrical distribution and avoid lagged observations, the applied conversion used decimal logarithm. Without such a conversion the lagged observations would impact on the assessment of the parameters in the path model. The proposed model was then tested, and the obtained assessment of the parameters describing the relations between the variables are shown in Figure 5.

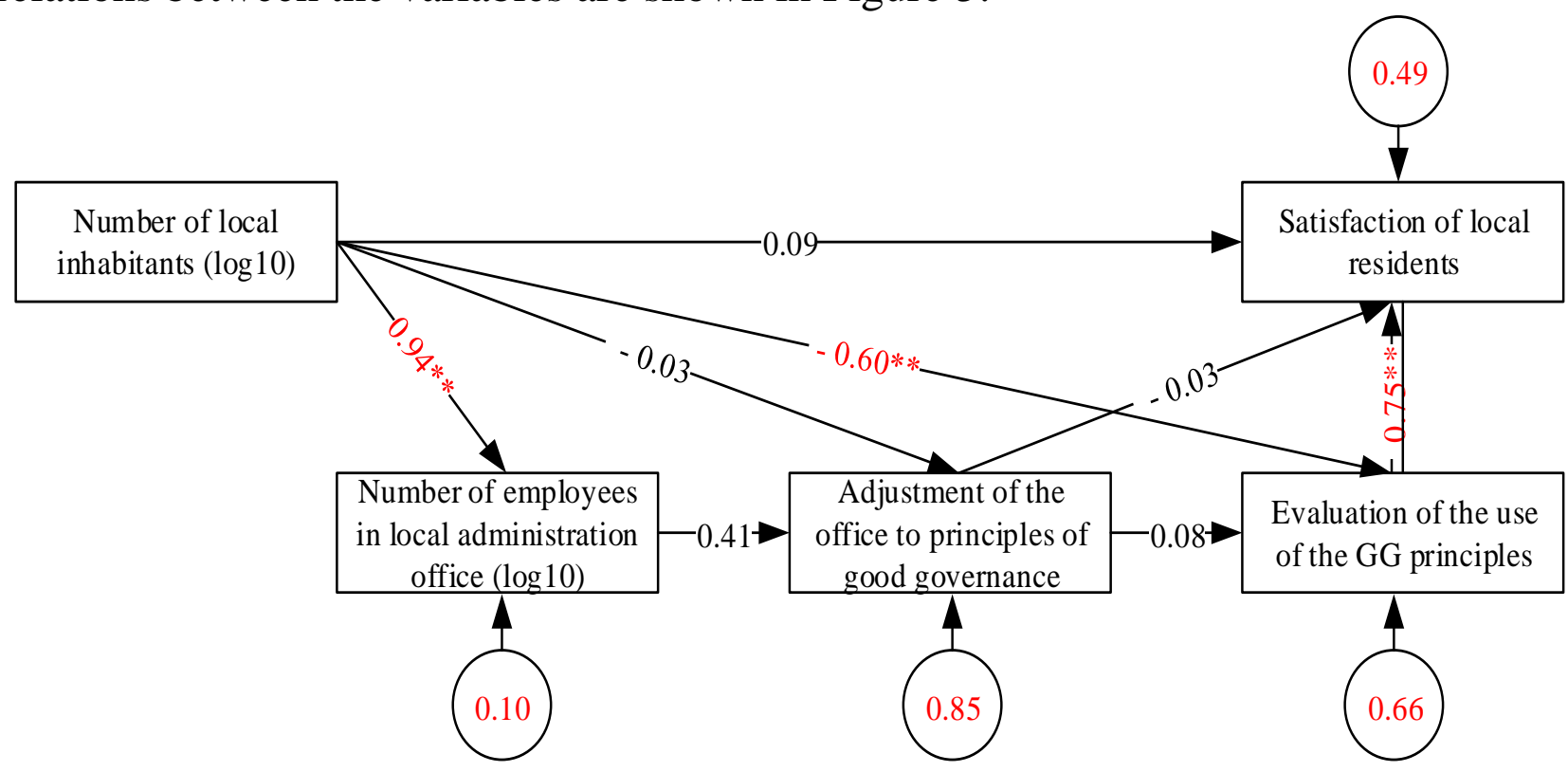

Fig. 5. Path diagram - the initial model with marked coefficients of paths and residual paths

$$
(* \mathrm{p}<0.05, * * \mathrm{p}<0.01)
$$

For the proposed model, value p of chi-square statistic was 0.07 , which indicates sufficient fit of the model. The value of standardized residue did not exceed 0.06 and amounted to 0.02. The Jöreskog coefficients GFI and AGFI were 0.94 and 0.53 , respectively. Therefore the majority of fit indices (except for AGFI) stays within the preferred ranges.

In order to increase fit of the model, in the subsequent steps we removed the paths whose parameters assumed statistically insignificant values. The final version of the path diagram showing the values of the paths' parameters is presented in Figure 6. 


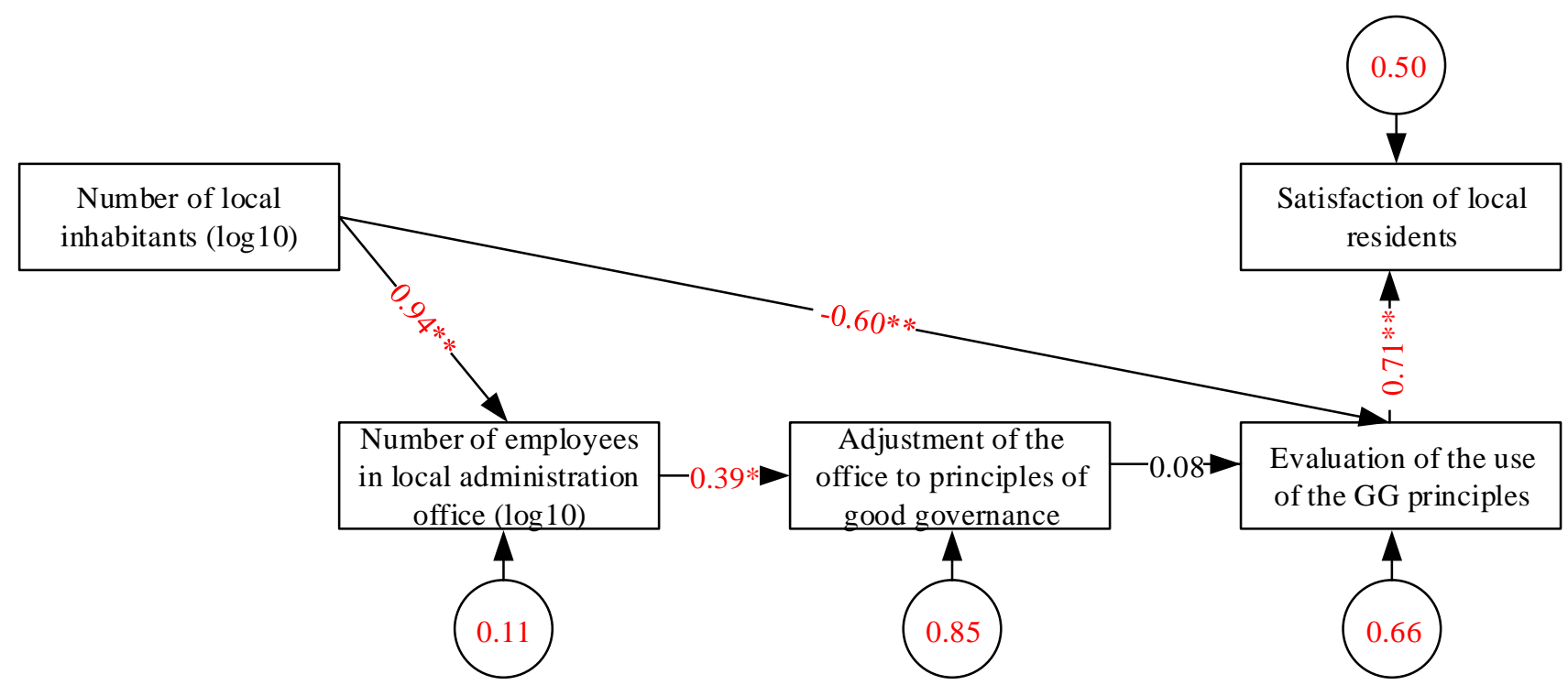

Fig. 6. Path diagram - the final model with marked coefficients of paths and residual paths $(* \mathrm{p}<0.05, * * \mathrm{p}<0.01)$

For the model presented in Figure 6 value p of chi-square statistic was 0.34, and the value of standardized residual did not exceed and amounted to 0.03 . The Jöreskog coefficients GFI and AGFI were 0.94 and 0.81, respectively. This means that all the fit indices remain within the preferred ranges. The proposed path model was subject to moderation according to the type of borough (i.e. it was verified whether dependencies in the model vary significantly depending on the additional control variable dividing the group into subgroups).

Table 4. Moderation of the path model in types of boroughs

The difference of chi-square statistics $-16,436$ for 10 degrees of freedom, $\mathrm{p}=0.0878$, standardized
residual RMS for varied parameters - 0.127; for equal parameters - 0.345.


Management Theory and Studies for Rural Business and Infrastructure Development eISSN 2345-0355. 2019. Vol. 41. No. 2: 135-152.

Article DOI: https://doi.org/10.15544/mts.2019.13

\begin{tabular}{|c|c|c|c|}
\hline$* \mathrm{p}<0.05, * * \mathrm{p}<0.01$ & Rural boroughs & $\begin{array}{c}\text { Rural-municipal bo- } \\
\text { roughs }\end{array}$ & Municipal borough \\
\hline$P_{21}$ & $0.842^{* *}$ & $0.749 * *$ & $0.977^{* *}$ \\
\hline$P_{32}$ & 0.319 & 0.305 & $0.608^{* *}$ \\
\hline$P_{43}$ & $0.563^{* *}$ & -0.490 & -0.106 \\
\hline$P_{54}$ & $0.730^{* *}$ & $0.650^{* *}$ & $0.676^{* *}$ \\
\hline$P_{41}$ & -0.164 & 0.077 & $-0.594^{*}$ \\
\hline$E_{1}$ & 0.291 & $0.439^{*}$ & 0.046 \\
\hline$E_{2}$ & $0.898^{* *}$ & $0.907 * *$ & $0.631^{*}$ \\
\hline$E_{3}$ & $0.705^{* *}$ & $0.772^{* *}$ & $0.561^{*}$ \\
\hline$E_{4}$ & $0.468^{*}$ & $0.578^{*}$ & $0.542^{*}$ \\
\hline
\end{tabular}

On analysing the obtained values of the paths' coefficients for the individual groups of boroughs, it should be indicated that in the case of municipal boroughs there exist similar dependencies as in the model without the introduced subdivision. The exception is the value of the coefficient of the influence of the management system's maturity on the good governance evaluation. In the case of the analysis conducted for all types of local administration offices it is positive, although statistically insignificant, while for municipal boroughs it is negative but also statistically insignificant.

In the case of municipal-rural boroughs there emerge two differences which should be highlighted. The first is related to the influence of the number of inhabitants in a borough on the evaluation of implementing the principles of good governance (in this case it is positive although statistically not significant). The second difference is, similarly as in the case of municipal boroughs, the existing negative dependence between the maturity of the management system and the evaluation regarding implementing the GG principles where the value of this relation remains at the statistically insignificant level.

In relation to rural boroughs it should be stressed the revealed positive dependence between the maturity of the management system and the evaluation of implementing the principles of good governance made by the inhabitants of a borough. This is relevant as the value of the relations coefficient is at a fairly high, statistically significant level $(\mathrm{p}<0.01)$. For rural boroughs, it signals the existing indirect influence of the management system's maturity on satisfaction. The strength of this influence, expressed as the ratio for indirect paths, amounts to 0.41 . This means that in the proposed model, in respect of the category of rural boroughs, there is a relation between the use of the good governance principles by the local administration offices according to the accepted model and the satisfaction of local residents.

The phenomena indicated owing to the conducted paths' analysis allow us to confirm the existence of a regularity based on the variability of relations between the maturity of local administration offices and the evaluation of its activities made by the borough's inhabitants depending on the type of borough. This means that such a diversification is also related to the size of a borough. 


\section{Conclusions}

The research results presented in this article together with their analysis, allow for the formulation of some relevant conclusions. First, evaluation of the use of the principles of good governance by inhabitants of a borough is linked to their satisfaction which points to the legitimacy of applying the concept of good governance in local government administration. However, in relation to the whole examined sample, no connection has been established between the proposed in the model modus operandi of local administration based on good governance principles, and the evaluation of their use by local residents, and their related satisfaction.

Yet it should be noted that this may be linked to such a variable as the size of a borough. This variable has a significant negative influence on the evaluation of implementing the principles of good governance and indirectly influences the satisfaction of the inhabitants with the activity of local administration. This aspect can be interpreted in the context of the distance between citizens and the authorities, which in the case of larger boroughs, for example municipalities, will impact on the evaluation of the local administration's activity. On the other hand, the number of local residents is reflected in the number of local administration clerks necessary to provide an adequate service, which prompts the creation of more advanced organizational solutions. The two mentioned phenomena can result in the fact that even with the use of path analysis, the relation between the degree of the local administration's adherence to the concept of good governance and the evaluation on the part of the inhabitants is not visible.

In relation to rural boroughs, usually small ones and more homogenous regarding the number of inhabitants, there is a visible link between the application of the principles of good governance in the local government offices and the evaluation made by the local residents. In this type of case, the distance between the citizens and the authorities is much smaller, and the inhabitants are usually better informed about matters related to local community.

From the management perspective, the conducted research allows to formulate the conclusion that the use of the principles of good governance in managing local administration offices in rural boroughs serves a purpose and is reflected both in the evaluation made by local residents and in their satisfaction.

This observation is important because of the fairly frequent conviction about the irrelevance of employing more advanced methods of management or the approach based on the concept of good governance in small public administration units. The existence of the above mentioned dependence becomes an even more important issue when considering that the concept of good governance usually finds its use through its operationalization in respect of countries or regions.

The obtained results also allow to determine further possible directions of research. Firstly, it seems relevant to establish the answer to the question about the connection between the use of certain detailed organizational solutions in the rural units of local government administration and the satisfaction on the part of local residents. In the case of municipal and rural-municipal boroughs, it is necessary to carry out extended research based on a sample more homogenous in relation to the population 
numbers, and to define the link between the use of the principles of good governance and the satisfaction of local residents. In the case of municipal and rural municipal boroughs, it is also worth trying to identify the possible ways of influencing the evaluation of work carried out by the local administration offices and the satisfaction of the local community.

\section{Acknowledgment}

The publication was the outcome of the project entitled "Adaptation of the management system of local government office to the good governance concept" which was financed by The National Science Centre, based on the decision no. DEC-2013/09/B/HS4/01143.

\section{References}

African Development Bank (1999). Bank Group Policy on Good Governance, OCOD.

Asian Development Bank (1999). Governance: Sound Development Management, ADB.

Besançon, M. (2003). Good Governance Rankings: The Art of Measurement, World Peace Foundation.

Bovens, M. (2000). Two Concepts of Accountability: Accountability as a Virtue and as a Mechanism, West European Politics, vol. 33, no. 5.

Brodie, E., Cowling, E., Nissen, N., Paine, A.E., Jochum, V., Warburton, D. (2009). Understanding participation: a literature review. Pathways through participation, Institute for Volunteering Research. Brussels.

Commission of The European Communities (2001). European Governance. A White Paper, June.

Drucker, P.F. (1963). Managing for Business Effectiveness. Harvard Business Review, May-

Galbraith, J. R. (2005). Designing the Customer-Centric Organization. A Guide to Strategy, Structure and Process. Jossey-Bass, San Francisco.

IFAD (1999). Good governance: an overview. International Fund for Agricultural Development, Rome.

Jessop, B. (2007). Promowanie dobrego rządzenia i ukrywanie jego słabości, "Zarządzanie Publiczne", No. 2/2007.

Jones, B., Brazzel M. (2006). The NTL Handbook of Organization Development and Change: Principles, Practices and Perspectives. Pfeiffer, San Francisco.

Knack, S., Kugler, M. (2002). Constructing an Index of Objective Indicators of Good Governance. PREM Public Sector Group. World Bank.

Langton, S. (1978). What is citizen participation? [in:] Langton S. (eds.), Citizen participation in America, Lexington Books, Lexington.

OECD (2010). Public Governance Reviews Towards More Effective and Dynamic Public Management in Mexico, OECD Publishing.

Piotrowski, S. J., Van Ryzin, G. (2007). Citizen Attitudes Toward Transparency in Local Government, The American Review of Public Administration, vol. 37, no. 3.

Qudrat-I Elahi, K., (2009). UNDP on good governance International, Journal of Social Economics, Vol. 36. No. 12.

Waterman, R. H., Peters, T. J., Phillips, J.R. (1980). Structure is not organization, Business Horizons, June.

Weisbord, M. B. (1976). Organizational diagnosis: six places to look for trouble with or without a theory, Group \& Organization Studies, Vol. 1 No. 4.

World Bank (1992). Governance and Development, Washington. 


\title{
GERAS VALDYMAS LENKIJOS RAJONU SAVIVALDYBĖS ADMINISTRA- CIJOSE IR KAIMIŠKOSE SENIŪNIJOSE
}

\author{
Witold Szumowski \\ Dr. Wroclaw Ekonomikos universitetas, Komandorska 118/120, 53-315 Wroctaw, \\ Tel. +48606215836, El. pašto adresas witold.szumowski@ue.wroc.pl
}

Pateikta 201905 01; priimta 20190630

Viešasis valdymas yra atsakas ị apribojimus, susijusius su viešojo administravimo pertvarkymo galimybėmis viešojo valdymo sektoriuje. Vienas iš svarbiausių viešojo valdymo principų buvo suformuluotas Pasaulio banko. Jo panaudojimas praktikoje yra apsprendžiamas formuojant ịvairius indeksus, kurie paprastai skirti šalims ir regionams. Moksliniame diskurse trūksta tyrimų, nusakančių galimybes pasitelkti gero valdynmo principus mažesniuose vietos valdžios strūktos dariniuose, tokiuose kaip rajonų savivaldybės administracijos ir kaimiškos seniūnijos. Taip pat, mažai atlikta mokslinių tyrimų, kurių rezultatai būtų susiję su viešojo administravimo institucijų veikla grịsta gero valdymo principais ir vietos gyventojų ịsitraukimu ị viešujų sprendimų prièmimą.

Sio tyrimo tikslas - geros valdymo koncepcijos igyvendinimas, sudarant savivaldybès administracijos veiklos modelį pagal gero valdymo principus, taip pat pasiūlan priemones, skirtas ịvertinti valdymo sprendimų brandos lygį, pagrịstą gero valdymo principais. Tyrimo rezultatai, susiję gero valdymo principų raiškos analize bei palyginimu su apklausos rezultatais atskleidžiančiais nuomonę ir pasitenkinimą rajono savivaldybių ir kaimiškų seniūnijų veikla.

Raktiniai žodžiai: geras valdymas, vietos valdžia, viešasis valdymas

JEL Codes: M10 D73. 